\title{
Heavy Metal Uptake of Corn Irrigated with Human Urine
}

\author{
Horacio Factura ${ }^{1}$, Glenda Factura ${ }^{2}$, Ralf Otterpohl ${ }^{3}$ \\ ${ }^{1}$ University of Science and Technology of Southern Philippines, Philippines \\ ${ }^{2}$ Xavier University-Ateneo de Cagayan, Philippines \\ ${ }^{3}$ Technische Universitaet Hamburg-Harburg, Germany
}

\section{Article Info}

Article history:

Received Jan 5, 2016

Revised Feb 9, 2017

Accepted Feb 18, 2017

\section{Keyword:}

Ecological sanitation

Groundwater contamination

Heavy metals in urine

Reuse of urine

\begin{abstract}
Pit latrine (PL) is one of the most common disposal systems for human excreta in low-income countries but because it is a hole in the ground, infiltration of liquid effluent into the soil can continuously occur. Poor sanitation systems permit the spread of heavy metals in urine to water bodies especially the groundwater. This study investigated the accumulation of heavy metals in shoots of corn plants irrigated with urine. A pot experiment with corn was conducted under greenhouse conditions. Urine was diluted to 3:1 ratio (water and urine respectively) and was compared to control (water only). Using Inductively Coupled Plasma Optical Emission Spectrometry (ICP-OES), heavy metals such as Boron, Barium, Cobalt, Copper, Iron, Manganese, Nickel, Silicon, Strontium and Zinc were detected in shoots of all plants with contents ranging from 0.22 to $2,487.44$ milligram (mg) per kilogram $(\mathrm{kg})$. The higher amounts detected in urine irrigated plants than the control proved the presence of the metals in the urine. Reuse of urine will definitely benefit farmers while at the same time reduce the risk of heavy metal contamination in groundwater.
\end{abstract}

Copyright () 2017 Institute of Advanced Engineering and Science. All rights reserved.

\section{Corresponding Author:}

Horacio Factura,

University of Science and Technology of Southern Philippines,

National Chung Cheng University,

168 University Road, Minhsiung Township, Chiayi County 62102, Taiwan, ROC.

Email: hfactura@must.edu.ph

\section{INTRODUCTION}

PL are one of the most common disposal systems for human excreta in low-income countries and used by an estimated 1.77 billion people as those countries continue aiming to meet the sanitation-related target of the Millennium Development Goals (Graham \& Polizzotto, 2013). Sixty-eight (68) percent of the world's population in 2015 had access to improved sanitation facilities including flush toilets and covered latrines compared with 54\% in 1990 (WHO, 2015). PL are basically characterized as a hole in the ground that collects urine and faeces, without any concrete flooring. Either no water is added into the pit after each defecation or 1 - 3 liters per flush with pour-flush PL (Tilley et al., 2014). Typically a pit is only 3 - 5 meters deep and 1 meter in width (Tilley et al., 2014; WORLD BANK GROUP). Each person produces 500 liters of urine per year (Otterpohl, 2000) and considering the number of users in every PL, the volume of urine generated per year is tremendously large for the capacity of a PL. Because of this, infiltration of liquid effluent into the soil can continuously occur and this scenario is a very serious environmental and health concern (as illustrated in Figure 1). Microbial and chemical contamination in groundwater associated with PL has been widely studied (Graham \& Polizzotto, 2013). Septic systems can contaminate groundwater with dissolved solids, Nitrate, anoxic constituents (Manganese, Iron and hydrogen sulfide), organic compounds and microorganisms (McQuillan, 2004). Contents of Nitrogen in human excreta is high and consumption of high Nitrate concentrations in drinking water is known to cause methemoglobinemia, and associations with cancer in humans have been observed (Graham \& Polizzotto, 2013). The United Nations General Assembly 
in 2010 recognized access to safe and clean drinking-water and sanitation as human right, and called for international efforts to help countries to provide safe, clean, accessible and affordable drinking-water and sanitation (WHO, 2015).

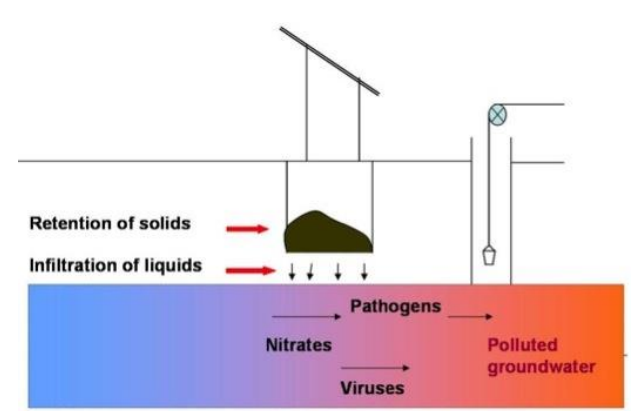

Figure 1. Schematic Presentation of a PL Showing Liquid Infiltration Into Groundwater (Source: GTZ)

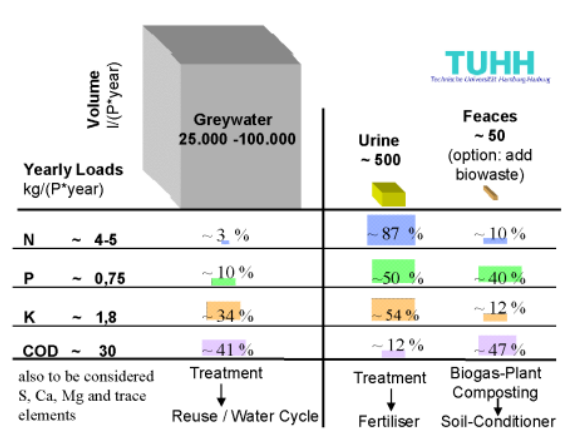

Figure 2. Composition of Domestic Wastewater (Otterpohl, 2000)

Urine normally mixes with flushing-water and faeces which altogether comprise the domestic wastewater (Otterpohl, 2000). Industrialized countries like Germany have sewerage systems capable of centralized collection and treatment of wastewater. In developing countries like the Philippines, wastewater treatment plants are not common. About 3\% of urban population in the Philippines are served with some form of sewerage facility and the rest rely on septic tanks or none at all (Roncesvalles, 2008). The Sanitation Code of the country clearly defined the standard septic tank which each household should follow (Mogol, 2008). However the majority install sub-standard structures to avoid the high cost. Just like PL, sub-standard designs allow the infiltration of wastewater through the soil which is extremely posing a very high risk of groundwater contamination.

Sanitation technologies have been developed to provide methods and techniques for the separate collection, treatment and reuse of human excreta (Otterpohl et al., 2002). Ecological sanitation (ecosan) is a cylce - a sustainable, closed-loop system, which closes the gap between sanitation and agriculture by recycling the nutrients contained in human excreta in crop production (Langergraber \& Muellegger, 2004). Terra Preta Sanitation (TPS) converts faecal matter through vermicomposting into hygienic organic matter that can be used to fertilize soil (Factura et al., 2010). TPS system (Figure 3) was successfully implemented in Xavier Ecoville, a resettlement community with 500 survivor families after typhoon Washi devastated Cagayan de Oro City, Philippines in 2011 (Factura et al., 2014). The World Health Organization (2006) published treatment guidelines that renders safe reuse of excreta in agriculture. A community urine diversion dehydration toilet (UDDT) as shown in Figure 4 has been widely implemented by various organizations especially in tropical countries of Asia and Africa (EcoSan Club, 2010; Gensch et al., 2010). Urine and faeces are separately collected and treated. Urine is stored in closed plastic container for at least 1 month before reuse.

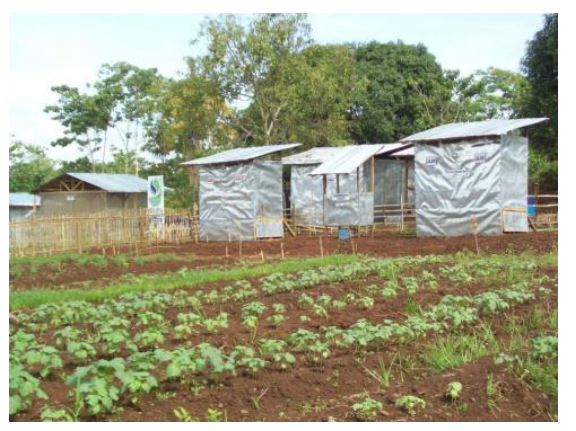

Figure 3. Facilities of the TPS System With Reuse of Urine in Vegetable Crops (Factura et al., 2014)

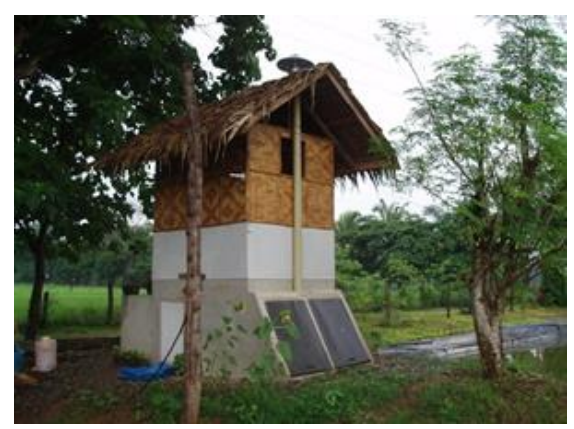

Figure 4. UDDT of the Periurban Vegetable Project in Manresa Farm, Xavier University-Ateneo de Cagayan, Cagayan de Oro City, Philippines 
The $\mathrm{pH}$ of fresh urine is normally between 4.8 and 7.5 but after collection it is around 9 and hygienizes (Höglund, 2001). Field experiments have scientifically proved urine's efficiency as comparable to chemical fertilizers in increasing crop yields (Muskolus, 2008; Höglund, 2001). Chemical analysis of urine revealed heavy metal contents (Cornelis et al., 1995; Fujimori et al., 1996; Zeiner et al., 2004) which are normally derived from food intake. However, studies dealing with plant tissue analysis after urine fertilization are still very limited. This study investigated the accumulation of heavy metals in shoots of corn plants irrigated with urine.

A pot experiment with corn was conducted under greenhouse conditions at the Institute of Wastewater Management and Water Protection, Hamburg University of Technology, Germany. Each plant was grown in a 5-liter plastic pot. The growing medium was a mixture of $73 \%$ woodchips, $18 \%$ soil and $9 \%$ sand. Undiluted urine was collected from a male diverting-toilet of a train station in a city located in Hamburg. Urine was diluted to 3:1 ratio (water and urine respectively). Control and the urine treatment were replicated 5 times in which control plants only received water. Irrigation schedule was the same for all pots including volume. Volume was increased gradually overtime. Light was provided for 12 hours per day. Twenty-six (26) days after sowing (DAS), plant height was measured from the base of the plant shoot up to the base of the last node. After measuring plant height, the plants were cut at the base of the shoot, placed individually in paper bags and dried in the oven. After drying, each plant shoot was milled and analyzed for heavy metal contents using ICP-OES at the Institute of Plant Nutrition, Leibniz University of Hannover, Germany.

\section{RESULTS AND DISCUSSION}

Control plants had grown up to an average of 20.76 centimeters $(\mathrm{cm})$ only and did not develop further. The plants were thin and stunted while their shoot color completely changed to purple. It is a clear indication of the absence of plant nutrients in the growing medium for plant biomass production. On the other hand, corn plants irrigated with urine showed normal growth and development. Biomass reached up to an average of 35.08 grams 26 DAS while control plants only had 0.67 grams in dry weight. Although not measured in the experiment, Nitrogen is normally the main nutrient in urine that is responsible for plant biomass production according to several studies (Morgan \& SEI, 2004; Höglund, 2001).

Table 1. Average Plant Height (cm) and Dry Weight (gram) At 26 Das

\begin{tabular}{ccc}
\hline Parameters & Control & Urine \\
\hline Plant height & 20.76 & 56.80 \\
Dry weight & 0.67 & 35.08 \\
\hline
\end{tabular}

Heavy metals were detected in shoots of all plants (Table 2). Results of the control plants basically indicated the presence of the elements in the growing medium. But the higher amounts detected in the urine irrigated plants than the control signified the presence of the metals in the urine (Table 2) that was used in the experiment. This finding is similar to the results of a study cited by the European Commission in 2013. Potatoes and onion shoots and leaves contained Nickel and Chromium after irrigation using contaminated water (European Commission - Science for Environmental Policy, 2013). Accumulation of heavy metals in above-ground tissue of Brassica juncea was related more closely to Copper, Lead and Zinc EDTAextractable concentrations in soils $(\mathrm{Cu}, 2015)$. Sweet potato grown in a mixture of municipal sewage sludge and yard waste media was found to have greater total concentrations of Lead, Nickel and Chromium in its plant parts than the control (Antonious et al., 2011). Crops cultivated around dumpsites had high metal concentrations $(\mathrm{mg} / \mathrm{kg})$ of Cobalt $(0.33)$ and Iron (0.32) in roselle leaves; Copper $(0.71)$ and As (0.37) in groundnut; Copper (0.48) and Arsenic (0.28) in maize grains; Arsenic (0.36) and Cobalt (0.32) in spinach leaves; and Copper (0.36) and Cobalt (0.32) in okro (Opaluwa et al., 2012). These are just few of the literatures which provided evidences that any heavy metal present in growing media or irrigation source can accumulate in plant parts once absorbed by the roots. While all the above-metioned elements are considered heavy metals, Copper, Zinc, Manganese, Iron, Nickel and Molybdenum are actually essential micronutrients for plants (Page \& Feller, 2015). 
Table 2. Average Heavy Metal Contents $(\mathrm{mg} / \mathrm{kg}$ ) In Shoots of the Control and Urine Irrigated Plants at 26 DAS

\begin{tabular}{ccc}
\hline Heavy metals & Control & Urine \\
\hline Barium & 20.26 & 52.33 \\
Boron & 21.01 & 30.04 \\
Cobalt & 0.87 & 0.95 \\
Copper & 6.11 & 8.64 \\
Iron & 15.51 & 41.95 \\
Manganese & 73.86 & 136.166 \\
Nickel & 2.58 & 3.68 \\
Silicon & 276.45 & 434.15 \\
Strontium & 0.22 & 4.67 \\
Zinc & 31.61 & 56.59 \\
\hline
\end{tabular}

Differences particularly in Barium, Boron, Iron, Silicon, Zinc and Manganese contents detected in plant shoots between the control and the urine treatment (Table 2) can be used as basis in stating that urine can be potentially hazardous to groundwater. Iron, Copper and Zinc are heavy metals in drinking water linked most often to human poisoning (Mohod \& Dhote, 2013).

The use of woodchips was a demonstration of a soil with poor structure and organic matter composition and as wells as low retention capacity for water and nutrient. The experiment had shown that the uptake and accumulation of heavy metals in plant shoots could proceed regardless of soil quality and this is an example of phytoremediation. Phytoremediation that uses the remarkable ability of plants to concentrate elements and compounds from the environment and to metabolize various molecules in their tissues appears very promising for the removal of pollutants from the environment (Nouri et al., 2009). The poor growth and development of the control plants did not hinder the absorption of heavy metals. With high biomass yield, reuse of urine can be recommended in crop production especially in areas with degraded and unproductive soils. Ecosan and TPS projects worldwide have successfully demonstrated holistic systems for collection, treatment and reuse of urine both in rural and urban agriculture (EcoSan Club, 2010; Gensch et al., 2010, Factura et al., 2014).

\section{CONCLUSIONS}

Heavy metals contributed by urine in domestic wastewater can be efficiently captured using hytoremediation technology. Reuse of urine will definitely benefit farmers and at the same time reduce the risk of heavy metal contamination in water bodies especially in areas where household sanitation systems are absent or poorly established

\section{REFERENCES}

[1] Antonious, G. F., Dennis, S. O., Unrine, J. M., and Snyder, J. C. (2011). "Heavy Metals Uptake in Plant Parts of Sweetpotato Grown in Soil Fertilized with Municipal Sewage Sludge," INTERNATIONAL JOURNAL OF GEOLOGY Issue 1, Volume 5, 2011.

[2] Cornelis, R., Heinzow, B., Herber, R. F. M., Molin Christensen, J., Paulsen, O. M., Sabbion, E., Templeton, D. M., Thomassen, Y., Vahter, M., and Vesterberg, O. (1995). "Sample Collection Guidelines for Trace Elements in Blood and Urine," Pure \& Applied Chemistry, Vol. 67, Nos 8/9, pp. 1575-1608

[3] $\mathrm{Cu}, \mathrm{N}$. X. (2015). "Effect of Heavy Metals on Plant Growth and Ability to Use Fertilizing Substances to Reduce Heavy Meta Accumulation by Brassica Juncea L. Czern," Global Journal of Science Frontier Research: D Agriculture and Veterinary, Volume 15 Issue 3 Version 1.0 Year 2015

[4] EcoSan Club (2010). Use of Urine. Sustainable Sanitation Practice. Müllegger, E., Langergraber, G., and Lechner, M. Issuue $3 / 2010$.

[5] Factura, H.; Bettendorf, T.; Buzie, C.; Pieplow, H.; Reckin, J.; Otterpohl, R. (2010): Terra Preta Sanitation: ReDiscovered from an Ancient Amazonian Civilization. Water Science \& Technology, 61 (10), 2673-2679, doi: 10.2166/wst.2010.201.

[6] Factura, H.; Medalla, J.; Masgon, M.; Miso, A.; Itchon, G.; Gensch, R.; Buzie, C.; Otterpohl, R. (2014): The Implementation and Practices of Terra Preta Sanitation in the Tropics - The Experiences from Xavier University Ateneo de Cagayan, Cagayan de Oro City, Philippines. Terra Preta Sanitation, Ed. Betterndorf, T., Wendland, C., Otterpohl, R. Deutsche Bundesstiftung Umwelt, ISBN 978-3-00-046586-4.

[7] Fujimori, E., Sawatari, H., Chiba, K., and Haraguchi, H. (1996). "Determination of Minor and Trace Elements in Urine Reference Sample by a Combined System of Inductively Coupled Plasma Mass Spectrometry and Inductively Coupled Plasma Atomic Emission Spectrometry", ANALYTICAL SCIENCES JUNE 1996, VOL. 12, 465-470. 
[8] Gensch, R., Miso, A., and Itchon, G. (2011): Urine as Liquid Fertilizer in Agricultural Production in the Philippines - a practical field guide, Xavier University Press, ISBN 978-971-9094-11-1

[9] Graham, J. P. and Matthew L. Polizzotto, M. L. (2013). Pit Latrines and Their Impacts on Groundwater Quality: A Systematic Review. Environ Health Perspect; DOI:10.1289/ehp.1206028, May 2013, Volume 121, Issue 5

[10] Höglund, C. (2001). Evaluation of microbial health risks associated with the reuse of source separated human urine. PhD thesis, Department of Biotechnology, Royal Institute of Technology, Stockholm, Sweden. ISBN 917283-039-5.

[11] Langergrabera, G. and Muelleggera, E. (2005). Ecological Sanitation-a way to solve global sanitation problems? Environment International 31 (2005) 433-444, doi:10.1016/j.envint.2004.08.006.

[12] McQuillan, D. (2004). GROUND-WATER QUALITY IMPACTS FROM ON-SITE SEPTIC SYSTEMS, In Proceedings, National Onsite Wastewater Recycling Association, 13th Annual Conference Albuquerque, NM, November 7-10, 2004.

[13] Mogol, G. (2008). Environmental and Occupational Health. Making sanitation A Priority: Successes and Challenges at the Local Level, Proceedings of the Visayas-Mindanao Regional Sanitation Summit, April 2-3, 2008, Dumaguete City, Center for Local and Regional Governance, Deutsche Gesellschaft fuer Technische Zusammenarbeit GmbH, pp. 35-40

[14] Mohod, C. V. and Dhote, J. (2013). REVIEW OF HEAVY METALS IN DRINKING WATER AND THEIR EFFECT ON HUMAN HEALTH. International Journal of Innovative Research in Science, Engineering and Technology, Vol. 2, Issue 7, July 2013, ISSN: 2319-8753, pp. 2992-2996

[15] Morgan, P. and SEI (2004). The Usefulness of Urine www.ecosanres.org/pdf_files/PM_Report/Chapter_10_The_usefuln...

[16] Muskolus, A. (2008). Anthropogenic Plant Nutrients as Fertilizers. PhD Thesis, Institut fur Pflanzenbauwissenschaften, Landwirtschaftlich- Gartnerischen Fakultat der Humboldt-Universitat zu Berlin, Germany.

[17] Nouri, J., Khorasani, N., and Lorestani, B. (2009). Accumulation of heavy metals in soil and uptake by plant species with phytoremediation potential. Environ Earth Sci (2009) 59:315-323, DOI 10.1007/s12665-009-0028-2.

[18] Opaluwa, O. Da., Aremu, M. Oa., Ogbo, L. Ob, Abiola, K. Ab., Odiba, I. Ec., Abubakar, M. Ma. and Nweze, N.O. (2012). "Heavy metal concentrations in soils, plant leaves and crops grown around dump sites in Lafia Metropolis, Nasarawa State, Nigeria". Advances in Applied Science Research, 2012, 3 (2):780-784, ISSN: 0976-8610.

[19] Otterpohl, R. (2000). Design of Highly Efficient Source Control Sanitation and Practical Experiences, EUROSummer School DESAR, June 18-23 2000, Wageningen, The Netherlands, https://cgi.tuharburg.de/ awwweb/susan/downloads/desar.pdf .

[20] Otterpohl, R., Braun, U., and Oldenburg, M. (2002). Innovative Technologies for Decentralised Wastewater Management in Urban and Peri-urban Areas, 5th Specialised Conference on Small Water and Wastewater Treatment Systems, Istanbul-Turkey, 24-26 September 2002, pp. 27-36.

[21] Page, V. and Feller, U. (2015). Heavy Metals in Crop Plants: Transport and Redistribution Processes on the Whole Plant Level. Agronomy 2015, 5, 447-463; doi:10.3390/agronomy5030447, ISSN 2073-4395.

[22] Roncesvalles, J. R. (2008). Towards Providing Sustainable Sewerage and Septage Management Services, Making sanitation A Priority: Successes and Challenges at the Local Level, Proceedings of the Visayas-Mindanao Regional Sanitation Summit, April 2-3, 2008, Dumaguete City, Center for Local and Regional Governance, Deutsche Gesellschaft für Technische Zusammenarbeit GmbH, pp. 42-45.

[23] Science for Environment Policy (2013): Vegetables can absorb heavy metals from contaminated irrigation water. European Commission DG Environment News Alert Service, SCU, The University of the West of England, Bristol. Issue 336, 11 July 2013.

[24] Tilley, E.; Ulrich, L.; Lüthi, C.; Reymond, Ph.; Zurbrügg, C. (2014). Compendium of Sanitation Systems and Technologies (2 ed.). Dübendorf, Switzerland: Swiss Federal Institute of Aquatic Science and Technology (Eawag). ISBN 978-3-906484-57-0.

[25] Zeiner, M., Ovari, M., Zaray, GY., and Steffan, I. (2004). Reference Concentrations of Trace Elements in Urine of the Budapestian Population. Biological Trace Element Research 107 Vol. 101, 107-115.

[26] WHO (2006). World Health Organization Guidelines for the Safe Use of Wastewater, Excreta and Greywater, Volume IV whqlibdoc.who.int/publications/2006/9241546824_eng.pdf.

[27] WHO (2015). World Health Organization Sanitation Fact sheet No 392. June 2015 http://www.who.int/mediacentre/factsheets/fs392/en/.

[28] WORLD BANK GROUP (2016). Toilet Options - Pit Latrines http://water.worldbank.org/shw-resourceguide/infrastructure/menu-technical-options/pit-latrines. 